Prepared as part of the Federal Water Cooperative Program and the National Streamflow Information Program

\title{
Hydrologic Conditions in Florida during Water Year 200
}

Scientific Investigations Report 2008-5221

U.S. Department of the Interior U.S. Geological Survey

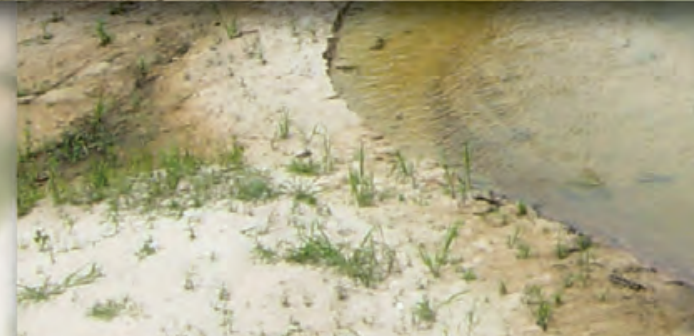


Cover: Ochlockonee River near Havana, Florida, June 25, 2007. Daily mean discharge was $35 \mathrm{ft} / \mathrm{s}$, gage height was 70.46 feet above NGVD 29. Photograph by USGS Hydrologic Technician Erik Ohlson.

Cover design by Jim Tomberlin. 
